\title{
Toxicological Evaluation of Tetrameles nudiflora Methanolic Extract
}

\author{
Sofna DS Banjarnahor ${ }^{1^{*}}$, Indah D Dewijanti ${ }^{1}$, Marissa Angelina ${ }^{1}$, Megawati $^{1}$, Sofa Fajriah ${ }^{1}$
}

${ }^{1}$ Research Center for Chemistry, Indonesian Institute of Sciences (LIPI) Kawasan Puspiptek, Tangerang Selatan, Banten, Indonesia

\section{ABSTRACT}

Exploration of Mekongga national park resulted in novel finding of anticancer property from Tetrameles nudiflora. The investigation of toxic features of $T$. nudiflora is vital for further studies of its pharmacological activities. Acute toxicity test was done on methanolic extracts of T. nudiflora in DDY mice. Animal models were ordered into five groups. Group 1 was given $1 \mathrm{ml}$ solution of $2.5 \%$ Tween 80 in a sole oral dose. The remaining groups were appointed a sole dose of $1,2,4$ and $8 \mathrm{~g} / \mathrm{kg}$ body weight $T$. nudiflora, respectively. Toxic effects of the extract were evaluated on the basis of behavioral observations in the form of locomotor activity; curiosity; defecation; urination and also animal mortality. Observations were carried out for 14 days. No significant changes in body weight and behavioral activities were recorded. Mortality was recorded up to $22 \%$ of the male group, and $11 \%$ of the female group. The T. nudiflora extracts tested for toxicity against brine shrimp had $50 \%$ lethal concentration (LC50) values of $46.67 \mu \mathrm{g} / \mathrm{ml}$. It can be concluded that methanol extracts of $T$. nudiflora are potential to be explored as anticancer (LC50 $=46.67 \mu \mathrm{g} / \mathrm{ml}$ ). The extract is slightly toxic in male mice with Lethal Dose 50 (LD50) $12.6 \mathrm{~g} / \mathrm{kg}$ body weight, and practically nontoxic for female (LD50>15 g/ $\mathrm{kg}$ body weight).

Keywords: acute oral toxicity, brine shrimp lethality test, LD 50, Tetrameles nudiflora

\section{INTRODUCTION}

Plant-derived bioactive components are potential to be developed as drugs. Indonesians have used herbals as traditional healing substances over decades. Currently, rapid changes have been observed in the use of popular natural products from plant sources for health maintenance and also for alternative therapies worldwide.

Tetrameles nudiflora, a member of Araceae family, is scarcely distributed in soft, damp and shady places. The natural habitat of $T$. nudiflora has wide distribution, namely Australia, Bangladesh, Bhutan, China, India, Laos, Malaysia, Myanmar, Sri Lanka, Thailand, Vietnam and Indonesia. In Indonesia, this plant is known as binong or winong and widely distributed throughout the island of Sumatra, Java, Sulawesi, Nusa Tenggara, and Papua [1]. A report by Kerala Forrest Research Institute described that decoction from the bark of this plant has been used as a laxative, diuretic agent, and anti-rheumatic [2]. Previous studies showed that the bark and leaves of $T$. nudiflora have potential

${ }^{*}$ Corresponding author:

Sofna DS Banjarnahor

Research Center for Chemistry, Indonesian Institute

of Sciences (LIPI), Kawasan Puspiptek, Banten, Indonesia

E-mail: sofna99@gmail.com therapeutic effects as anti-allergy and anti-cancer [3]. Limited information regarding the safety of $T$. nudiflora is available.

Toxicity is the expression of hazardous substances as the consequence of interactional activity between toxicants and hosts. This toxic relationship may vary relying on the chemical features of the toxicants and cell membrane, as it may present either on or inside the cellular milieu or in the extracellular matrix. Manifestations of the toxic effects can occur at any stage prior to the binding with major organs like kidneys and liver.

Exposure to chemical despite being natural are not always safe and can create a hostile response in human's body [4]. Thus, investigation of the potential toxicity of a substance is critical when developing plant-derived bioactive drugs.

Various methodologies for toxicity testing are available namely acute, sub-chronic, chronic, carcinogenic, and specific functional tests. The objective of this study was to characterize the potential toxicity of methanol extract of $T$. nudiflora leaves using two standardized methods including brine shrimp bioassay and acute oral toxicity in animal models. 


\section{MATERIALS AND METHODS}

\section{Plant Sample}

Tetrameles nudiflora was collected from Mekongga forest, southeastern part of Sulawesi in March 2012. The voucher specimen has been deposited in the Herbarium Bogorienses, Research Centre for Biology, Indonesian Institute of Sciences.

\section{Methanolic extraction}

Fresh whole plants were dried and cut into small pieces (1280 gr) before extracted comprehensively using macerator in $\mathrm{n}$-hexane and methanol at room temperature for three times before evaporated using vacuum technique to obtain the thick extract.

\section{Phytochemical screening}

Phytochemical screening enables the detection of secondary metabolites in a plant extract. This is performed as a procedure towards the identification of potential lead compounds in the extract [5]. Tests for certain leading compounds were performed according to Fehling's test, Lead subacetate test, Frothing test, Shinoda test, Liebermann-Burchard's test, Mayer's test, Dragendroff s test, Wagner's test, and Borntrager's test.

\section{Brine shrimp lethality test Hatching shrimp}

Brine shrimp eggs were incubated in a tank contains sterile artificial seawater composed of $38 \mathrm{~g}$ table salt in $1 \mathrm{~L}$ distilled water. The tank was kept under an inflorescent bulb and provided with proper aeration for $48 \mathrm{~h}$ at room temperature. After brooding, nauplii discharged from the eggshells were collected at the flashing side of the tank by using micropipette. The larvae were sequestered from the eggs by aliquoting them in a small beaker containing the seawater.

\section{Brine shrimp test}

The brine shrimp lethality test was used to monitor the presence of cytotoxic activity of the extract [6]. The extract was dissolved in methanol and diluted with artificial seawater. The assay was performed by formulating solution consisting of seawater in a series of concentrations from 100 to $0.195 \mathrm{mg} / \mathrm{mL}$. Potassium dichromate was dissolved in artificial seawater and functioned as a positive control with concentrations extending from 0.1 to $0.9 \mathrm{mg} / \mathrm{mL}$. An aliquot $(0.1 \mathrm{~mL})$ containing about 10 to 15 nauplii was administered to each bottle, and the setup was allowed to continue for $24 \mathrm{~h}$. The bottles were monitored, and the dead larvae from each bottle were calculated after 6 and $24 \mathrm{~h}$.
Table 1. Phytochemical screening of Tetrameles nudiflora methanolic fraction

\begin{tabular}{ccc}
\hline No & Compound & \\
\hline 1 & Alkaloid & $(-)$ \\
2 & Flavonoid & $(-)$ \\
3 & Terpene & $(+)$ \\
4 & Saponin & $(+)$ \\
\hline
\end{tabular}

$(-)=$ negative; $(+)=$ positive

The concentration that resulted in 50\% lethality (LC50) to the nauplii was prescribed by using the graph of mean percentage mortality in contrast with the log of concentration [7]. The average results of mortality percentage of the brine shrimp against the log of concentrations were plotted using the Microsoft Excel spreadsheet application, which also expressed the regression equations. These equations were further used for calculating LC50 values for the samples tested. A value less than $1000 \mu \mathrm{g} / \mathrm{mL}$ is considered cytotoxic [6].

\section{Acute Oral Toxicity and LD50 Determination}

The acute oral toxicity of $T$. nudiflora methanol extract was examined in mice as specified in the procedure profiled by the Organization for Economic Cooperation and Development (OECD) with modification [8]. The experimental procedures were performed upon approval from the Ethics Committee Medical Faculty, University of Indonesia.

The experiment was conducted on 50 healthy DDY mice of both sexes weighing between $25-30 \mathrm{~g}$, aged 8 to 10 weeks obtained from the Laboratory of Non-Ruminant, Veterinary Faculty, Bogor Agricultural Institute. The animals were subjected to acclimatization for a week before used, and fed with standard growers mash feeds and water ad libitum. These mice were randomly distributed into five groups, i.e., four treated

Table 2. Means of general appearances and behavioral observations. The observations expressed in more than half of the group; $\mathrm{N}=$ Normal.

\begin{tabular}{ccccccccccc}
\hline \multirow{2}{*}{ Observation } & \multicolumn{1}{c}{ Male } & \multicolumn{1}{c}{ Female } \\
\cline { 2 - 11 } & 1 & 2 & 3 & 4 & 5 & 1 & 2 & 3 & 4 & 5 \\
\hline Skin and fur & $\mathrm{N}$ & $\mathrm{N}$ & $\mathrm{N}$ & $\mathrm{N}$ & $\mathrm{N}$ & $\mathrm{N}$ & $\mathrm{N}$ & $\mathrm{N}$ & $\mathrm{N}$ & $\mathrm{N}$ \\
Eyes & $\mathrm{N}$ & $\mathrm{N}$ & $\mathrm{N}$ & $\mathrm{N}$ & $\mathrm{N}$ & $\mathrm{N}$ & $\mathrm{N}$ & $\mathrm{N}$ & $\mathrm{N}$ & $\mathrm{N}$ \\
Mucous membrane & $\mathrm{N}$ & $\mathrm{N}$ & $\mathrm{N}$ & $\mathrm{N}$ & $\mathrm{N}$ & $\mathrm{N}$ & $\mathrm{N}$ & $\mathrm{N}$ & $\mathrm{N}$ & $\mathrm{N}$ \\
Behavioral patterns & $\mathrm{N}$ & $\mathrm{N}$ & $\mathrm{N}$ & $\mathrm{N}$ & $\mathrm{N}$ & $\mathrm{N}$ & $\mathrm{N}$ & $\mathrm{N}$ & $\mathrm{N}$ & $\mathrm{N}$ \\
Salivation & $\mathrm{N}$ & $\mathrm{N}$ & $\mathrm{N}$ & $\mathrm{N}$ & $\mathrm{N}$ & $\mathrm{N}$ & $\mathrm{N}$ & $\mathrm{N}$ & $\mathrm{N}$ & $\mathrm{N}$ \\
Lethargy & $\mathrm{N}$ & $\mathrm{N}$ & $\mathrm{N}$ & $\mathrm{N}$ & $\mathrm{N}$ & $\mathrm{N}$ & $\mathrm{N}$ & $\mathrm{N}$ & $\mathrm{N}$ & $\mathrm{N}$ \\
Sleep & $\mathrm{N}$ & $\mathrm{N}$ & $\mathrm{N}$ & $\mathrm{N}$ & $\mathrm{N}$ & $\mathrm{N}$ & $\mathrm{N}$ & $\mathrm{N}$ & $\mathrm{N}$ & $\mathrm{N}$ \\
Diarrhea & $\mathrm{N}$ & $\mathrm{N}$ & $\mathrm{N}$ & $\mathrm{N}$ & $\mathrm{N}$ & $\mathrm{N}$ & $\mathrm{N}$ & $\mathrm{N}$ & $\mathrm{N}$ & $\mathrm{N}$ \\
\hline
\end{tabular}


Table 3. Potential toxic effects of methanolic extract of Tetrameles nudiflora. a: Control group (Treatment with Tween 80); b: Test groups; c: Number of dead mice/number of mice used.

\begin{tabular}{ccc}
\hline & Male & Female \\
\hline $1(\text { control })^{\mathrm{a}}$ & $0 / 10^{\mathrm{c}}$ & $0 / 10$ \\
$2(1 \mathrm{~g} / \mathrm{kgbw})^{\mathrm{b}}$ & $0 / 10$ & $0 / 10$ \\
$3(2 \mathrm{~g} / \mathrm{kgbw})$ & $1 / 10$ & $0 / 10$ \\
$4(4 \mathrm{~g} / \mathrm{kgbw})$ & $5 / 10$ & $3 / 10$ \\
$5(8 \mathrm{~g} / \mathrm{kgbw})$ & $6 / 10$ & $1 / 10$ \\
\hline
\end{tabular}

groups and one control group of the opposite sex.

Prior to the actual study, a preliminary test on a small group of mice was carried to determine dose ranges. A single dose of $1,2,4$, and $8 \mathrm{~g} / \mathrm{kg}$ body weight of T. nudiflora were administered orally. Before handling, mice were kept fasted overnight to remove the feed from the digestive tract. All mice were thoroughly examined after suspension administration immediately for the emergence of any toxic signs and once daily afterward for 14 days of the treatment period to document any late-onset toxic effects. Survival, feed consumption, and body weight were monitored. The LD50 of the extract was calculated using the arithmetic method of Reed and Muench [9].

\section{Organ and Body Weight Analysis}

On $14^{\text {th }}$ day, surviving mice were sacrificed. Gross necropsy was conducted, and organs were weighted. Sample of livers, kidneys, and hearts were taken for histological study. The animals were dissected and careful examinations of selected organs were carried out. Tissue samples were embedded in $10 \%$ buffered formalin, regularly processed and fixed in paraffin wax. Paraffin sections $(5 \mu \mathrm{m})$ were sliced on glass slides and dyed with hematoxylin and eosin. The selected tissue sections were examined under a light microscope [Zeiss Primo Star, DMCe, (x40)] and the amplified images of the tissues structure were captured for further study [10].

\section{Statistical Analysis}

Results are demonstrated as the mean \pm SD. Behavioral observations, body weight, organ weight, and food intake were tested by conducting One-Way ANOVA using SPSS 17 statistical software.

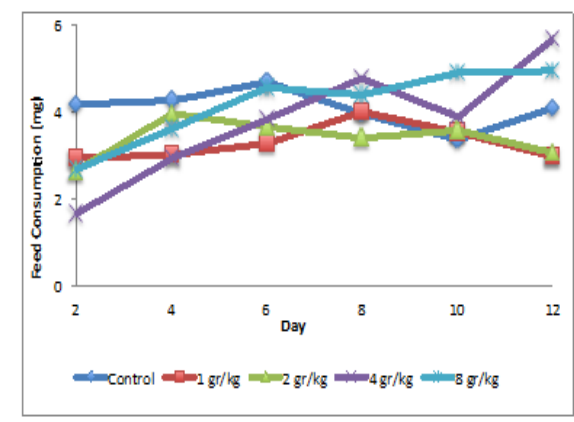

B

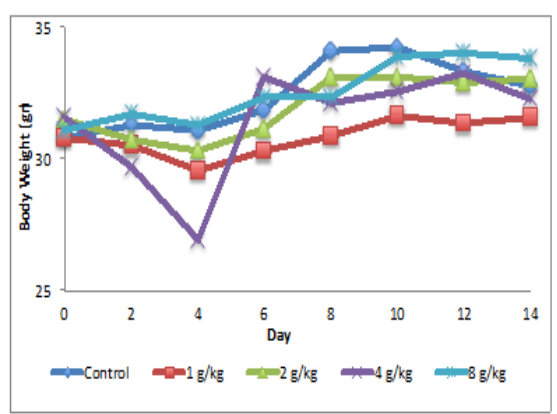

D

Figure 1. Feed consumption during the 14 days of treatment in male mice (A) and female mice (B). Body weight changes during the 14 days of treatment in male mice (C) and female mice (D) 
Table 4. Effect of T. nudiflora methanolic extract on organ-tobody-weight index (\%) in male (A) and female (B) mice. Organ body index $=($ organ weight $\times 100) /$ body weight; values are mean $\pm \mathrm{SD}, \mathrm{P}<0.05$

\begin{tabular}{lcccccccc}
\hline \multirow{2}{*}{ No } & Group & $\begin{array}{c}\text { Body } \\
\text { Weight } \\
\end{array}$ & Heart & Lungs & Liver & Kidneys & Spleen & Testis \\
\hline 1 & Control & 34.96 & $0.54 \pm 0.07$ & $1.41 \pm 0.17$ & $7.89 \pm 1.05$ & $1.52 \pm 0.12$ & $1.23 \pm 0.53$ & $0.59 \pm 0.10$ \\
2 & $1 \mathrm{~g} / \mathrm{kgbw}$ & 34.54 & $0.43 \pm 0.06$ & $0.77 \pm 0.09$ & $6.91 \pm 1.51$ & $1.39 \pm 0.14$ & $0.92 \pm 0.26$ & $0.64 \pm 0.14$ \\
3 & $2 \mathrm{~g} / \mathrm{kgbw}$ & 31.49 & $0.43 \pm 0.1$ & $0.83 \pm 0.13$ & $6.63 \pm 1.53$ & $1.44 \pm 0.45$ & $0.90 \pm 0.28$ & $0.65 \pm 0.13$ \\
4 & $4 \mathrm{~g} / \mathrm{kgbw}$ & 28.56 & $0.59 \pm 0.1$ & $1.12 \pm 0.21$ & $6.15 \pm 1.88$ & $1.43 \pm 0.37$ & $1.01 \pm 0.12$ & $0.54 \pm 0.22$ \\
5 & $8 \mathrm{~g} / \mathrm{kgbw}$ & 28.73 & $0.55 \pm 0.16$ & $1.53 \pm 0.26$ & $7.67 \pm 1.14$ & $1.30 \pm 0.44$ & $1.16 \pm 0.21$ & $0.68 \pm 0.13$ \\
\hline
\end{tabular}

A

\begin{tabular}{|c|c|c|c|c|c|c|c|c|}
\hline \multirow[b]{2}{*}{ No } & \multirow[b]{2}{*}{ Group } & \multirow{2}{*}{$\begin{array}{c}\text { Body } \\
\text { Weight } \\
(\mathrm{gr})\end{array}$} & \multicolumn{6}{|c|}{ Organ-to-body-weight (\%) } \\
\hline & & & Heart & Lungs & Liver & Kidneys & Spleen & Ovarium \\
\hline 1 & Control & 32.8 & $0.46 \pm 0.05$ & $0.76 \pm 0.07$ & $6.93 \pm 0.82$ & $1.44 \pm 0.13$ & $0.92 \pm 0.38$ & $0.10 \pm 0.04$ \\
\hline 2 & $1 \mathrm{~g} / \mathrm{kgbw}$ & 32.03 & $0.56 \pm 0.08$ & $0.99 \pm 0.15$ & $7.12 \pm 1.19$ & $1.36 \pm 0.15$ & $0.97 \pm 0.59$ & $0.04 \pm 0.03$ \\
\hline 3 & $2 \mathrm{~g} / \mathrm{kgbw}$ & 33.03 & $0.47 \pm 0.07$ & $0.87 \pm 0.14$ & $6.19 \pm 0.47$ & $1.36 \pm 0.19$ & $0.52 \pm 0.3$ & $0.05 \pm 0.03$ \\
\hline 4 & $4 \mathrm{~g} / \mathrm{kgbw}$ & 32.27 & $0.45 \pm 0.15$ & $1 \pm 0.31$ & $6.32 \pm 1.21$ & $1.22 \pm 0.2$ & $0.66 \pm 0.27$ & $0.10 \pm 0.13$ \\
\hline 5 & $8 \mathrm{~g} / \mathrm{kgbw}$ & 33.8 & $0.49 \pm 0.07$ & $0.70 \pm 0.17$ & $6.02 \pm 0.48$ & $1.23 \pm 0.14$ & $0.55 \pm 0.25$ & $0.21 \pm 0.28$ \\
\hline
\end{tabular}

B

\section{RESULTS AND DISCUSSION \\ Extraction and Phytochemical Screening}

1.28 kilogram $(1.28 \mathrm{~kg})$ of the dried leaves of $T$. nudiflora yielded $185 \mathrm{gr}$ of the crude extract equivalent to $14.45 \%$. The extract is a dark brown thick oily substance and kept at room temperature (in a bottle). Phytochemical screening results showed the extract was composed of terpenes and saponins (Table 1).

\section{Acute Oral Toxicity and LD50 Determination}

The potential toxicity effect of the methanol extracts of Tetrameles nudiflora on the manifestation and behavioral motif mice are shown in Table 2. Alterations of feed consumption and also body weight during the treatment is one of the quantitative criteria for toxic effects. Mean amounts of feed intake by male mice in the treated groups and the control group are shown in Figure 1A. Likewise, the same profile is also noticed on the treated and the control group of female mice (Fig. 1B). Both sexes showed no significant changes of feed and fluid consumption.

Monitoring of weight showed no significant changes $(P>0.005)$ as seen in Figure $1 \mathrm{C}$ and Figure 1D. The body weight of the female mice given the highest dose during the first days of treatment showed a significant decrease (Fig. 1D) $(\mathrm{P}<0.05)$. This indicates that the extract might have potential effect on metabolism with increasing dose.

However, it could be argued that these fluctuations may not be toxic, as they were not corroborated with other findings (organ weight, gross necropsy). None of the animals expressed any behavioral changes, and no changes, or toxic signs or symptoms were noticed. Accordingly, it seems likely that methanolic extracts of $T$. nudiflora administered by the nasopharyngeal route are not toxic at the doses studied.

Up to the provision with the largest dose $(8 \mathrm{~g} / \mathrm{kg}$ body weight), the LD50 by Reed Muench can be calculated. LD50 calculation results based on mortality data as presented in Table 3, showed that the LD50 value in the group of females is apparent; this means that the methanol extract of $T$. nudiflora is practically nontoxic. Meanwhile, the value of LD50 for male mice was $12.6 \mathrm{~g} / \mathrm{kg}$ body weight. This value indicates that for male mice, the methanol extract of $T$. nudiflora is slightly toxic [11].

Organs such as the heart, lungs, liver, kidney, and spleen are strongly influenced by the presence of metabolites of toxicants [12]. Therefore, assessment of organ-to-body-weight index is also the frontline markers of potential toxicity of a substance. Measurements of relative organ weight in both the control and the treatment mice are presented in Table $4 \mathrm{~A}$ and Table $4 \mathrm{~B}$. Based on the data obtained, no significant weight changes $(P>0.05)$ were found from the vital organs.

Evaluation of internal organs is beneficial for assessing the toxic spectrum of the extracts, which organs are potentially undermined by the presence of toxicants. The changes of structure and function in cells, tissues, organs and even organ system in the body can be used as a marker of the metabolic effects of contaminants [13]. Gross necropsies of both sexes showed no significant changes as presented in Table 5.

Drugs metabolism is recruiting major organs, including the small intestine, lung, kidney, and plasma. However, the liver is the most metabolically active for the majority of drug metabolism [14]. The pericentral zone, which is closest to the central vein, is poorly oxygenated; therefore this area has become the most vulnerable site in the liver [15]. Histopathology of the

Table 5. Histopathological findings in mice treated orally with Tetrameles nudiflora for 14 days of treatment. 1=Control, $2=1 \mathrm{mg} / \mathrm{kgbw}, 3=2 \mathrm{mg} / \mathrm{kgbw}, 4=4 \mathrm{mg} / \mathrm{kgbw}$, $5=8 \mathrm{mg} / \mathrm{kgbw} ; \mathrm{M}=$ Male, $\mathrm{F}=$ Female; $0=$ No finding

\begin{tabular}{|c|c|c|c|c|c|c|c|c|c|c|c|}
\hline \multirow{2}{*}{ Organs } & \multirow{2}{*}{ Parameters } & \multicolumn{2}{|c|}{1} & \multicolumn{2}{|c|}{2} & \multicolumn{2}{|c|}{3} & \multicolumn{2}{|c|}{4} & \multicolumn{2}{|c|}{5} \\
\hline & & $\mathrm{M}$ & $\mathrm{F}$ & $\mathrm{M}$ & $\mathrm{F}$ & M & $\mathrm{M}$ & M & $\mathrm{F}$ & $\mathrm{M}$ & $\mathrm{F}$ \\
\hline \multirow[t]{3}{*}{ Liver } & Hemorrhage & 0 & 0 & 0 & 0 & 0 & 0 & 0 & 0 & 0 & 0 \\
\hline & Vacuolar degeneration & 0 & 0 & 0 & 0 & 0 & 0 & 0 & 0 & 0 & 0 \\
\hline & Wegener & 0 & 0 & 0 & 0 & 0 & 0 & 0 & 0 & 0 & 0 \\
\hline \multirow[t]{2}{*}{ Kidneys } & Interstitial calcification & 0 & 0 & 0 & 0 & 0 & 0 & 0 & 0 & 0 & 0 \\
\hline & Cystic disease & 0 & 0 & 0 & 0 & 0 & 0 & 0 & 0 & 0 & 0 \\
\hline \multirow[t]{2}{*}{ Heart } & Focal myocardial degeneration & 0 & 0 & 0 & 0 & 0 & 0 & 0 & 0 & 0 & 0 \\
\hline & Inflammatory cell infiltration & 0 & 0 & 0 & 0 & 0 & 0 & 0 & 0 & 0 & 0 \\
\hline
\end{tabular}




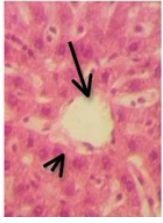

A

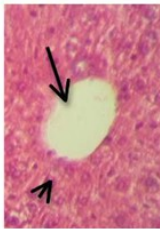

F

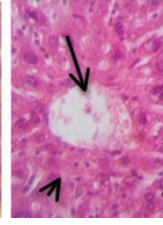

B

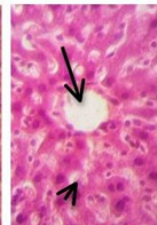

G

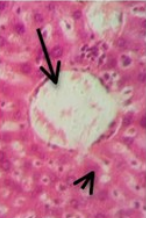

C

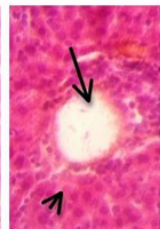

$\mathrm{H}$

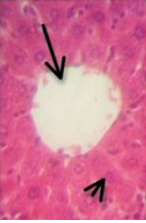

D

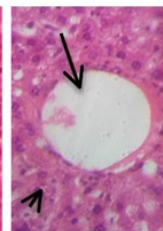

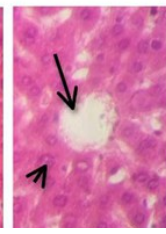

E

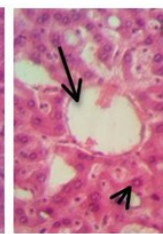

J

Figure 2. Liver section of male (top: A, B, C, D, E) and female (bottom: F, G, H, I, J) mice. A\&F: Control; B\&G: 1 gr/kgbw; C\&H: 2 gr/kgbw; D\&I: 4 gr/kgbw; E\&J: 8 gr/kgbw; long arrows (central vein); short arrows (hepatocyte). (H\&E, 40x).

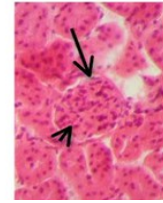

A

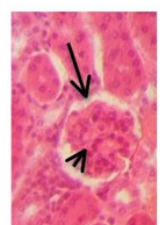

F

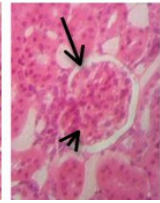

B

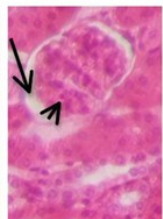

G

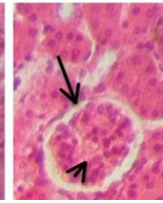

C

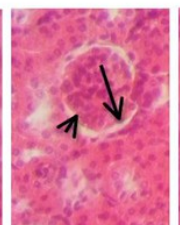

$\mathrm{H}$

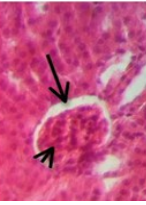

D

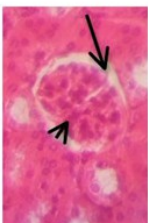

I

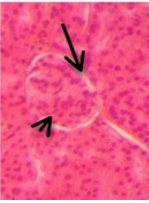

E

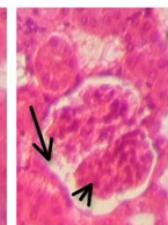

J

Figure 3. Kidney section of male (top: A, B, C, D, E) and female (bottom: F, G, H, I, J) mice. A\&F: Control; B\&G: 1 gr/kgbw; C\&H: 2 gr/kgbw; D\&I: 4 gr/kgbw; E\&J: 8 gr/kgbw; long arrows (central vein); short arrows (hepatocyte). (H\&E, 40x).

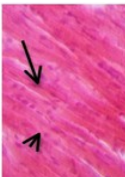

A

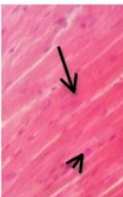

F

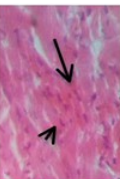

B

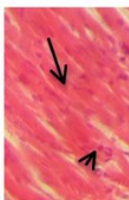

G

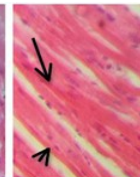

C

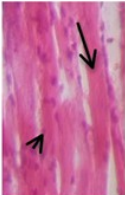

$\mathrm{H}$

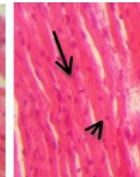

D

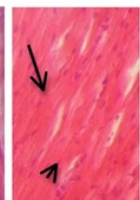

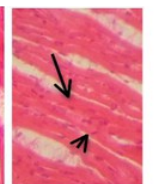

E

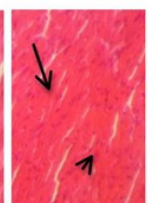

J

Figure 4. Heart section of male (top: A, B, C, D, E) and female (bottom: F, G, H, I, J) mice. A\&F: Control; B\&G: 1 gr/kgbw; C\&H: 2 gr/kgbw; D\&I: 4 gr/kgbw; E\&J: 8 gr/kgbw; long arrows (central vein); short arrows (hepatocyte). (H\&E, 40x). 


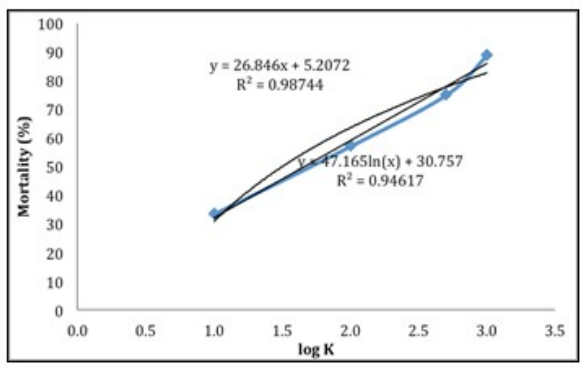

Figure 5. Brine shrimp lethality test

liver sections in each group showed normal hepatic structure and normal liver lobular architecture (Figure 2). Methanolic extract of $T$. nudiflora results in no significant differences in the structure of the central vein $(\mathrm{P}>0.05)$ in each group.

The kidney is a complex organ consisting of one million functional units. This organ is responsible to filter out around 150-180 liters of plasma per day and to produce hormones that are critical to maintain the work of certain tissues.

These complex functions and structures handle the sensitivity to toxicants due to its function [16]. According to Kincaid-Smith and Whitworth, measuring the number of cells of the glomerulus and glomerular diameter is very useful to detect disorders of the kidneys. Damage to the kidneys is due to lysis of the glomerular cells, resulted in the shortening of glomerular diameter and enlarging the space between the Bowman's capsule and the glomerulus [17]. The results as seen in Figure 3 , show unnoticeable differences in the histological section of the kidneys between the control and the treatment group in both sexes. These findings indicate that methanolic extract of $T$. nudiflora produces no significant changes in kidney tissue.

Conventionally, the heart has been considered as a rare target for the development of toxic lesions compared to more common target tissues such as the liver and kidneys. However, in recent years, the heart is increasingly acknowledged as an important focus for a variety of toxic agents, including environmental pollutants, chemicals, and drugs. Heart tissue has a limited regenerative function. Thus, it will lose its function as tissue is destroyed. Inflammation caused by the effects of free radicals can lead to cellular changes and structural abnormalities of the heart.

These free radicals cause the instability of the heart muscle cells by affecting the lipid bilayer membranes, proteins, and DNA base composition. Damage to the heart muscle will change the shape of the cytoplasmic membrane lipid bilayer due to rupture and lead to necrosis [18,19]. Microscopic sections of the cardiac tissue (Figure 4) show no cardiotoxic effects.

\section{Brine Shrimp Lethality Test}

Brine shrimp lethality test of the methanolic extracts of $T$. nudiflora express as mortality percentage versus $\log$ of concentration is shown in Figure 5. The methanolic extracts resulting in LC50 values of less than $1 \mathrm{mg} / \mathrm{mL}$ are considered as significantly active. $T$. nudiflora extract with LC50 value of $46.67 \mu \mathrm{g} / \mathrm{mL}$ have a strong toxicity and potential to be used as anticancer agent [20]. Additionally, there is a direct corresponding relation between the concentration of the extract and the degree of lethality.

\section{CONCLUSIONS}

Our results indicate that the methanolic extract of Tetrameles nudiflora appears to be slightly toxic when administered acutely through the enteral route in male mice, however no consistent histopathological changes in internal organs were showed in each group. In female mice, the administration of Tetrameles nudiflora is practically safe to be consumed through oral administration. Further biochemical studies to furnish more information relating to the toxicity are recommended.

\section{ACKNOWLEDGMENT}

This study was sponsored by the LIPI Competitive Research Grant 2012-2014. Authors are thankful to Prof. Dr. Sci. Muhammad Hanafi for his support and collaboration.

\section{REFERENCES}

1. Priyadi H (2010) Five Hundred Plant Species in Gunung Halimun Salak National Park, West Java: A Checklist Including Sundanese Names, Distribution, and Use. Center for International Forestry Research. p. 16.

2. Sasidharan N, Chand Bhasha, S, Renuka C (1999) Botanical Studies In The Medicinal Plant Conservation Areas In Kerala. KFRI Research Report.

3. Rameshwar Dayal, Dobhal PC (2001) Tetrameles nudiflora - A new potential source of bryonolic acid. Journal of Medicinal and Aromatic Plant Sciences. 23(4): 660-661.

4. Asante-Duah K (2002) Public Health Risk Assessment for Human Exposure to Chemicals (illustrated ed.); Kluwer Academic Publishers: Dordrecht. The Netherlands. Volume 6 .

5. Tiwari P, Kumar B, Kaur M, Kaur G, Kaur H (2011) Phytochemical Screening and Extraction: A Review. International Pharmaceutica Sciencia. 1(1): 98-106.

6. Meyer BN, Ferrigni NR, Putnam JE, Jacobsen LB, Nichols 
DE, McLaughlin JL (1982) A convenient general bioassay for active plant constituents. Planta Med. 45: 31-34.

7. Islam MK, Eti IZ, Chowdury JA (2009) Cytotoxic studies on two Meliaceae plants: Chukrasia tabularis and Aglaia roxburghiana. J. Sci. Res. 1: 399-403.

8. OECD Guidelines for acute toxicity of chemicals (2001) No. 420.

9. Agrawal SS, Paridhavi M (2007) Herbal drug technology. Universities press, India. p. 607-614.

10. Mcmanus JGA, Mowry RW (1984) Staining Methods: Histological and Histochemical; Harper and Row: New York, NY, USA.

11. Loomis TA (1978) Essential of toxicology. 3rd ed. Philadelpia. Lea \& Febiger. p. 198 - 202.

12. Dybing E, Doe J, Groten J, Kleiner J, O'Brien J (2002) Hazard characterization of chemicals in food and diet: dose response, mechanism and extrapolation issues. Food Chem. Toxicol. 42: 237-82.

13. Adeyemo OK (2008) Histological Alterations Observed in the Gills and Ovaries of Clarias gariepinus exposed to environmentally relevant lead concentrations. Journal of Environmental Health. 70(9): 48-51.

14. Remmer MDH (1970) The role of the liver in drug metabolism. The American Journal of Medicine. 49(5): 617-629.

15. Vollmar B and Menger MD (2009) The Hepatic Microcirculation: Mechanistic Contributions and Therapeutic Targets in Liver Injury and Repair. Physiol Rev. 89: 12691339.

16. Bonventre JV, Vaidya VS, Schmouder R (2010) Next-generation biomarkers for detecting kidney toxicity. Nat Biotechnol. 28(5): 436-440

17. Kincaid-Smith P and Whitworth JA. 1987. The kidney-a clinicopathological study. Blackwell, Oxford.

18. Lai HC, Yeh YC, Wang LC et al. (2011) Propofol ameliorates doxorubicin-induced oxidative stress and cellular apoptosis in rat cardiomyocytes. Toxicology and Applied Pharmacology. 257(3): 437-48.

19. Deavall DG, Martin EA, Horner JM, Roberts R (2012). Drug-Induced Oxidative Stress and Toxicity. Journal of Toxicology. 2012: 1-13.

20. Clarkson C, Vineshm JM, Neil RC, Olwen MG, Pamisha P, Motlalepula GM, Niresh B, Peters JS, Peter IF (2004) In vitro antiplasmodial activity of medicinal plants native to or naturalized in South Africa. J. Ethnopharmacol. 92: 177-191. 